\title{
The Benefit of a Punitive God: The Story of Ananias and Sapphira
}

\author{
A. Jerry Bruce, Marsha J. Harman \\ Sam Houston State University
}

\begin{abstract}
In this narrative, we explore the story of Ananias and Sapphira from the book of Acts in the Christian scriptures. We examine the story in the light of a recent book by Dominic Johnson (2016), God Is Watching You, and other related research. The idea of a punitive God and/or the belief in a punitive God may have significant effects on group functioning. The troubling story of Ananias and Sapphira may be seen as a central cog in the cooperative coming together of what became the Christian Church. In our modern world, a punitive God is an idea we seek to avoid but it may be the one that is essential for a peaceful cooperative world.
\end{abstract}

Keywords: punitive God, cooperation, Early Church, psychology of religion

Jesus was not the first Jewish messianic figure in the time around his existence nor was he the last (Wise 1999), but he is the only one with 2.2 billion followers today (Pew Research Center, 2015). What was there about the movement around him that created his followers' success and the others Messiahs not so much?

In the early part of the book of Acts, the disciples have seen Jesus disappear from them and are told that he will come again (Acts 1:11), the disciples return to Jerusalem and gather in the upper room for earnest prayer, and they cast lots to choose a replacement for Judas (Acts 1:26). On the day of Pentecost, the group is set on fire by the Holy Spirit and in preaching to the multitude in Jerusalem many persons are brought into the community of disciples (Acts chapter 2). At this point, the disciples are said to have created a kind of commune.

All the believers were together and had everything in common. They sold property and possessions to give to anyone who had need. Every day they continued to meet together in the temple courts. They broke bread in their homes and ate together with glad and sincere hearts, praising God and enjoying the favor of all the people. And the Lord added to their number daily those who were being saved. (Acts 2:42-47)

It was as if time had expired and they were fashioning a new Jerusalem. It reminds me of Peter's declaration on the mount of transfiguration. "Peter said to Jesus, 'Rabbi, it is good for us to be here. Let us put up three shelters - one for you, one for Moses and one for Elijah' (He did not know what to say, they were so frightened)" (Mark 9:5-6). In such grand experiences, there is the desire to stop everything and create a timeless space in which to live.

Jerry Bruce, Ph.D., Prof., Department of Psychology and Philosophy, Sam Houston State University, USA; main research field: Psychology.

Marsha Harman, Ph.D., Prof., Department of Psychology and Philosophy, Sam Houston State University, USA; main research field: Psychology.

All quoted scriptural references are from the New International Version of the Bible. 
In chapter three of Acts, in the glow of these first days, scripture says that Peter and John participated in a remarkable healing, and Peter delivered another sermon, like on Pentecost. The growth of the community of disciples and the dramatic events aroused the authorities to action and in chapter 4 of Acts there is an arrest and a warning to Peter and John to stop this talk of Jesus. And the question is will all this stop the disciples?

With great power, the apostles continued to testify to the resurrection of the Lord Jesus. And God's grace was so powerfully at work in them all that there were no needy persons among them. For from time to time, those who owned land or houses sold them, brought the money from the sales and put it at the apostles' feet, and it was distributed to anyone who had need. (Acts 4:33-35)

Now the question becomes: How long will this glow of excitement and cooperation last? They were looking for Jesus to return quickly and if that did not happen, what would the results be? Greater persecution was sure to follow.

There is a very familiar story in Acts, chapter 5, of Ananias and Sapphira. The story begins with Joseph of Cyprus, to whom the disciples had given the name Barnabas, selling some property. Barnabas it would appear was a person of some means and had sold his real estate bringing the money to the disciples. He gave all the money that he had received from the transaction to the disciples. One would suspect that he gave a rather sizeable donation. It may have even been this event that caused the apostles to call him Barnabas, meaning son of encouragement (Acts 4:36). He had helped the group greatly and his example was encouraging others to do likewise. He was no doubt admired and praised by the disciples and the whole church. Now this is a good story. It ends happily and makes all who read it feel good. But the story is not over.

The principle of imitation, vicarious learning, is well documented in psychology (Bandura \& Walters 1963) as a guiding principle of social learning. The church was greatly impressed with Barnabas and others were following his example, and, therefore, the financial needs of the church were being met we can assume. But as every parent knows, children often need more than good models to bring them to the exhibition of cooperation and righteous behavior.

Ananias and Sapphira, also wealthy landowners within the early group of followers, wanted the same kind of adulation that Barnabas had received. They may have been a bit jealous of the attention that Barnabas was receiving. So they, following the example of Barnabas, sold some of their real estate and brought the money to the church. One small difference, Ananias and Sapphira conspired to keep some of the money but pretended that they were giving it all. After all, times were probably difficult and to be financially secure reasonable people would not want to deplete their entire savings.

Ananias first came with the money and gave it to Peter, the leader of the young group at that time. "Then Peter said, 'Ananias, how is it that Satan has so filled your heart that you have lied to the Holy Spirit and have kept for yourself some of the money you received for the land?'” (Acts 5:3) Peter acknowledged that the land belonged to Ananias, after the sale of the land the money belonged to Ananias, and there was no requirement that he gave all the money. Why then did he have to lie about what had occurred? Ananias died of shock there at Peter's feet.

Three hours later, Sapphira came in with the same lie and the same results. They were buried side by side. The scriptures say, "Great fear seized the whole church and all who heard about these events” (Acts 5:11).

It is useful to note, "The occurrence of the word 'church' (GK ekklesia) in verse 11 is its first occurrence in the original text of Acts” (Bruce 1954, 116). Now keep in mind that these early disciples were Jewish people 
who worshiped in the Temple and considered themselves members of the congregation of the Jewish nation. The idea of a new movement separate and apart from these roots surely must have only come with a great deal of angst. This first use by the writer of Acts of the term we translate as church was perhaps of some moment. It is as if this event initiates the group of people following the way of Christ to see themselves as the church for the first time, a group of people committed to the truth of the gospel, with the reality that they were operating under the watchful eyes of God.

Dominic Johnson (2016) in a recent book, God Is Watching You, hypothesizes that the notion of divine punishment is one of the, if not the most important, evolutionary prerequisite for cooperation. He closes the book with this sentence, "But in order to help self-interested and fallible humans get along, the gods have had to be cruel to be kind" (244). Could it be that this event in Acts sets the stage for the church to become a cooperative group of people with a common goal?

In the earliest days of the emerging Christian church existing within a context of hostile forces, a sense of cooperation among those identifying with the group would have been essential. The book of Acts in the Christian scriptures is a major source of our information about the development of the first century church. The story of Ananias and Sapphira is one of the early stories from this source and surely was preserved for the important effect it had on the emerging group.

This story was always a troubling one for many of us. It just did not seem to meet the standard of a compassionate procedure that we considered appropriate. The story seemed so harsh, so unloving, and so un-Christ-like. Where was compassion? Restraint? Where was the opportunity to repent? Judas was even dealt with less harshly! Over time many of us simply accepted the fact that these things were beyond our ability to understand. Dominic Johnson's book has helped us to understand the importance and perhaps central importance of this story.

Johnson notes that across the globe and throughout time, people have always believed in and practiced some sort of religion, and, further, the religion has almost always been ".. accompanied by a seemingly rather specific belief in supernatural punishment” (242). Furthermore, much modern research has affirmed the relationship between belief in a "mean" god or in the existence of hell tending to produce a greater respect for the rules of the social group.

To illustrate, Shariff and Norenzayan (2011) in laboratory studies using undergraduate students and focusing on cheating behavior, found that students' views of God, loving, or punishing, made a significant difference in their cheating behavior. Those seeing God as more punitive had significantly lower measures of cheating.

Moving to non-laboratory measures and looking at nations and their crime rates, Shariff and Rhemtulla (2012) found that in those countries (67 countries) where the belief in hell was strongest there was a lower crime rate, whereas, in those with greater focus on heaven the crime rate was higher. They state in their discussion, "Indeed, these findings coalesce with theoretical and empirical work suggesting that beliefs in punishing and omniscient supernatural agents spread across historical societies primarily because of their ability to foster cooperation and suppress anti-social behavior among anonymous strangers” (3).

Some might suggest that in our world today, religion belief in God is not as important as it once was. However, Johnson argues that those who seem to think religion is on its way out such as Dawkins (2006) and Harris (2004) are in error. In some European state, there is decline in traditional religion but if the globe as whole is examined, religion is not diminishing. Johnson refers to research done by Norris and Inglehart (2004) 
who found that the major religions (Catholicism, Hinduism, Protestantism, and Islam) have increased from 50\% of the world's population in 1900 to 64\% in 2000 (Johnson 2016, 226). Religion is more prevalent than ever before, and besides for those who would dump religion on to the ash-heap of history, should they not first consider what important role is being played by this universal characteristic of human beings. We might find that in the end without religion, divine punishment, the fear of God, we simply cease to exist, at least as a cooperative species.

Again, the truth is religion is not fading from the scene. Yang (2016) illustrates that the reverse is true. Referring to a recent Pew Research Center Report (2015), entitled "Why Muslims Are Rising Fastest and Unaffiliated Are Shrinking as a Share of the World's Population,” Yang notes that the relative birth rates of these two groups play a significant role in the rate of growth or decline. She goes on further to note that the rise of a Christian population in China may reflect an inaccurate picture of the Christian share of population.

Yang says, “... a proper definition of religion may have direct relevance for maintaining social order and stability" (14). Yang, in order to project a definition of religion, quotes from the book, Religion in China: Survival and Revival under Communist Rule, "a religion is a unified system of beliefs and practices about life and the world relative to the supernatural that unite the believers or followers into a social organization or moral community" (15).

"Therefore, we can say that belief in the supernatural is the core of religion, the absolute minimum thing in relation that is irreducible or irreplaceable" (Yang 2011, 15). We would hasten to add that this supernatural force in religion, this minimum element, must include a punitive aspect. In order to have a cooperative community, there needs to be a sense of a punitive power to keep cooperation at a reasonable level.

Back to the story of Ananias and Sapphira, without this story and its impact, the church may have never come into being much less survived. Groups can always attempt to impose a kind of police force to impose cooperation among its members. But empirical research such as that of Liao, Hong, and Zhang (2014) show that a third party "police” works much better than the internal group members attempting to control the group. As Johnson (2016) also suggests, the economics are much better when an outside spiritual force is conceived as the monitor of cooperative behavior. You don't have to pay the force, but you do need the group to believe the force is out there. In another place, Johnson, McDermott, Cowden, and Tingley (2012) assert the central place of belief or confidence in the reality of the force. The story in Acts may have served as the mechanism of convincing the church that there was a serious force out there.

The book Resident Aliens by Stanley Hauerwas and William H. Willimon (1989), put it this way, "Turning people toward God is, as Acts 5 shows, a terrifying task. The congregation may burst forth in exuberant spirit (Acts 2) or they may drop dead of fear (Acts 5)" (136). The notion that God was indeed a presence that must be reckoned with was richly apparent in those early days. The mindset of the church was moved to a point of increased cooperation. Even in sharing all that they possessed, see Acts 4.

What may have kept the church working cooperatively may have been the Ananias and Sapphira affair. According to Johnson (2016), it was the fear of divine retribution that enabled the human groups to cooperate. Evolutionarily speaking it had value in removing policing from the group which is costly, and placing it into the hands of an unseen force that was always watching. Although Johnson is speaking of the Puritans and their beliefs in a punitive God at Plymouth, the same could be applied to the Early Church in Jerusalem. "Remarkable as such beliefs appear today, they may have been instrumental in fostering the cooperation necessary to survive, and later grow, against the odds...” (175). 
We could also speak of Jeremiah and his "punitive" picture of God as the driving force that produced Judaism in the 6th and 5th centuries BCE. Why was that rather long, rather negative view of the Hebrew people, included in the Prophets, indeed one of the major prophets. Perhaps it was like Ananias and Sapharia in proclaiming that God indeed does punish those who violate the covenant.

In our time when we hesitate to see God in a punitive light, maybe we have lost some of the cooperative spirit that is needed for the church to operate cooperatively in our world. Of course, there are other theories of why the human animal became cooperative (Griffith 2016). Our timidity to paint God as punitive may make the idea of cooperation less viable, but among those people who hold to the belief in a punitive God perhaps their way will in the end have greater survival value due to increased cooperation (Johnson 2005). In discussing his research on this subject, Johnson (2016) says, “These are only correlations, of course, so we don't know if moralizing gods caused more cooperation (or vice versa), but it is consistent with the theory that the two should be associated" (184).

\section{Works Cited}

Bandura, Albert and Richard H. Walters. Social Learning and Personality Development. New York: Holt, Rinehart, and Winston, 1963.

Bruce, Frederick F. Commentary on the Book of Acts. Grand Rapids, MI: Wm. B. Eerdman Publishing Company, 1954.

Dawkins, Richard. The God Delusion. New York: Houghton Mifflin, 2006.

Griffith, Jeremy. Transform Your Life and Save the World. Sydney, Australia: World Transformation Movement, 2016.

Harris, Sam. The End of Faith: Religion, Terror, and the Future of Reason. New York: Norton, 2004.

Hauerwas, Stanley and William H. Willimon. Resident Aliens: Life in the Christian Colony. Nashville, TN: Abingdon Press, 1989. Johnson, Dominic. God Is Watching You: How the Fear of God Makes Us Human. New York: Oxford University Press, 2016.

Johnson, Dominic D. P. “God’s Punishment and Public Goods: A Test of Supernatural Punishment Hypothesis in 186 World Cultures.” Human Nature 16.4 (2005): 410-46.

Johnson, Dominic D. P., Rose McDermott, Jon Cowden, and Dustin Tingley. "Confidence and Conservatism Predict Aggression in Simulated International Crisis Decision-Making.” Human Nature 23.1 (2012): 98-126. Doi: 10.1007/s12110-012-9134-z.

Liao, Yuling, Kairong Hong, and Liang Zhang. "Punishment as a Mechanism to Maintain Bilateral Cooperation: A Social Behavior Experiment.” Social Behavior and Personality $42.9 \quad$ (2014): 1445-56. $<$ http//ds.doi.org/10.2224/sbp.2014.42.9.1445>.

Norris, Pippa and Ronald Inglehart. Sacred and Secular: Religion and Politics Worldwide. Cambridge: Cambridge University Press, 2004.

Pew Research Center. The Future of World Religions: Population Growth Projections, 2020-2050. Author, 2015. Retrieved from Pew Research Center. <http://www.pewforum.org/files/2015/03/PF_15.04.02_ProjectionsFullReporty.pdf>.

Shariff, Azim F. and Ara Norenzayan. "Mean Gods Make Good People: Different Views of God Predict Cheating Behavior.” The International Journal for the Psychology of Religion 21 (2011): 85-96. Doi: 10.1080/10508619.2011.556990.

Shariff, Azim F. and Mijke Rhemtulla. "Divergent Effects of Belief in Heaven and Hell on National Crime Rates.” PLoS ONE 7.6 (2012): e39048. Doi: 10.1371/journal.pone.0039048.

Wise, Michael O. The First Messiah. New York: Harper San Francisco, 1999.

Yang, Fenggang. “Exceptionalism or Chinamerica: Measuring Religious Change in the Globalizing World Today.” Journal for the Scientific Study of Religion 55.1 (2016): 7-22.

Yang, Fenggang. Religion in China: Survival and Revival under Communist Rule. New York: Oxford University Press, 2011. 